\title{
Partitioning Field Evapotranspiration Fluxes by Using Stable Oxygen Isotope during Different Maize Growth Stages
}

\author{
Congzhi Zhang \\ State Experimental Station of Agro-Ecosystem in Fengqiu \\ State Key Laboratory of Soil and Sustainable Agriculture, Institute of Soil Science \\ Chinese Academy of Sciences, Nanjing 210008, China \\ Tel: 86-25-8688-1349 E-mail: czzhang@issas.ac.cn \\ Jiabao Zhang (Corresponding author) \\ State Experimental Station of Agro-Ecosystem in Fengqiu \\ State Key Laboratory of Soil and Sustainable Agriculture, Institute of Soil Science \\ Chinese Academy of Sciences, Nanjing 210008, China \\ Tel: 86-25-8688-1228Ｅ-mail: jbzhang@issas.ac.cn \\ Bingzi Zhao \\ State Experimental Station of Agro-Ecosystem in Fengqiu \\ State Key Laboratory of Soil and Sustainable Agriculture, Institute of Soil Science \\ Chinese Academy of Sciences, Nanjing 210008, China \\ Tel: 86-25-8688-1230Ｅ-mail: bzhao@issas.ac.cn
}

Anning Zhu

State Experimental Station of Agro-Ecosystem in Fengqiu

State Key Laboratory of Soil and Sustainable Agriculture, Institute of Soil Science

Chinese Academy of Sciences, Nanjing 210008, China

Tel: 86-25-8688-1232 E-mail: anzhu@issas.ac.cn

Hui Zhang

Institute of Agricultural Resources and Environmental Sciences

Jiangsu Academy of Agricultural Sciences, Nanjing 210014, China

Tel: 86-25-8439-1171Ｅ-mail: 1983hui@sina.com

Received: June 29, 2011

doi:10.5539/jas.v4n3p11
Accepted: July 20, $2011 \quad$ Online Published: December 29, 2011

URL: http://dx.doi.org/10.5539/jas.v4n3p11

The research is financed by National Natural Science Foundation of China (41001128), National Basic Research Program of China (973 Program) (2011CB100506), and the Knowledge Innovation Program of the Chinese Academy of Sciences (KSCX2-EW-N-08).

\section{Abstract}

Field evapotranspiration is an important component in Soil Plant Atmosphere Continuum (SPAC), and it is comprised of plant transpiration and soil evaporation. However, the two components of which is difficult to partition. A field experiment was conducted in the Northern China to determine the maize transpiration and soil 
evaporation during a maize growth period using stable oxygen isotope. A water balance model in field was used to estimate the field evapotranspiration. Maize transpiration and soil evaporation were estimated during the five typical growth stages of seedling, jointing, booting, tasseling, and filling-mature, respectively. The results showed that total field evapotranspiration during the whole maize growth period was $481.8 \mathrm{~mm}$ and distributed in the five growth stages were $122.7,81.9,82.5,71.5$ and $123.2 \mathrm{~mm}$, respectively, and the fraction of maize transpiration in field evapotranspiration in the five growth stages were $11.8 \%, 65.0 \%, 78.3 \%, 81.8 \%$, and $50.02 \%$, respectively.

Keywords: Field evapotranspiration, Field water balance model, Maize transpiration, Soil evaporation, Isotope mass balance model

Abbreviations: SPAC, Soil Plant Atmosphere Continuum; $E T$, evapotranspiration; $T$, plant transpiration; $E$, soil evaporation; $\delta^{18} \mathrm{O}$, oxygen isotopic composition; $q$, soil water flow flux; $K$, unsaturated hydraulic conductivity; $\varphi$, soil water potential; $D$, distance; $K_{s}$, saturated hydraulic conductivity; $S$, saturation; $\theta$, soil volumetric water content; $\theta_{r}$, soil residual volumetric water content; $\theta_{s}$, soil saturated volumetric water content; $F_{E}$, the fraction of soil evaporation in the field evapotranspiration; $F_{T}$, the fraction of plant transpiration in the field evapotranspiration; $R^{18} \mathrm{O}$, molar ratio of heavier to lighter oxygen isotope; $h$, atmospheric relative humidity; $\alpha_{K}$, kinetic fractionation factor; $\alpha_{e q}$, equilibrium fractionation factor; $T$, soil temperature; $m$ mass of water (presented as mm); $P$, precipitation; $S_{c}$, field moisture capacity; $C$, the concentrations of the $\mathrm{H}_{2} \mathrm{O}$.

\section{Introduction}

Water cycle in Soil Plant Atmosphere Continuum (SPAC) has been the popular research topic since Philip firstly advised the conception of SPAC in 1966 (Philip, 1966). In order to understand the water sources or sinks in SPAC and mass balance mechanism in agroecosystem, one of the key problems is to realize the water transporting and transitions in field. Field evapotranspiration is an important component in SPAC, which is composed by plant transpiration and soil evaporation and is difficult to estimate (Yepez et al., 2003).

Micrometeorologic methods such as Bowen ratio model and eddy covariance had been used to calculated evapotranspiration (Williams et al., 2004; Wilson et al., 2001; Paco et al., 2006; Sun et al., 2008), but usually limited by much parameters and complicated calculation processes. Large-scale weighing lysimeter made direct measurements of water loss from growing crop and the soil surface around crop (Vaughan et al., 2007), and thus, the measurement was exact in some extent, but it has poor spatial representation (Yepez et al., 2003; Jarvis, 1995). Water balance model have been widely applied to determined field evapotranspiration (Steinwand et al., 2006), while exact and precise methods are needed for obtaining the components of the model such as precipitation and infiltration or capillary rise.

Crop transpiration was significant for determining water use efficiency in field (Allen et al., 2003), and which could be measured precisely by portable photosynthesis system, but the measurement results only represented the instantaneous state of the leaf level. Therefore, partition plant transpiration and soil evaporation in field from evapotranspiration was necessary and difficult (Baldocchi et al., 1988; Scott et al., 2003; Yepez et al., 2003). Although evaporation from soil surface in some greenhouse experiments could be inhibited by enclosing the pots (Li, 1999; Zhao et al., 2004), soil evaporation was unavoidable in field. Water vapor evaporated from soil surfaces was strongly fractionated and its isotope composition was significant difference from isotope composition of leaf water (Flanagan et al., 1991); Therefore, an isotope mass balance model could be used to partition evapotranspiration into its components and was presented as follows(Yakir and Sternberg, 2000):

$$
\begin{gathered}
E T=E+T \\
E T \delta_{E T}^{18} \mathrm{O}=E \delta_{E}{ }^{18} \mathrm{O}+T \delta_{T}{ }^{18} \mathrm{O}
\end{gathered}
$$

where $E T$ was evapotranspiration, $T$ was maize transpiration, and $E$ was soil evaporation. $\delta_{E T}{ }^{18} \mathrm{O}, \delta_{T}{ }^{18} \mathrm{O}$ and $\delta_{E}{ }^{18} \mathrm{O}$ were the oxygen isotopic composition of evapotranspiration, transpiration, and evaporation water, respectively.

The model had been widely applied in the water flux studies in forest (Moreira et al., 1997), orchard (Williams et al., 2004), grassland (Ferretti et al., 2003), while few had been conducted in field crops due to the accurate values of $E T, \delta_{E T}{ }^{18} \mathrm{O}, \delta_{T}{ }^{18} \mathrm{O}$ and $\delta_{E}{ }^{18} \mathrm{O}$ in the model were difficult to obtain in field crops.

Huang-Huai-Hai Plain, located in northern China, is an important grain production base that accounts for about $30 \%$ of the grain produced nationally in China. The main crop grown in this area is maize. It is important to evaluate water consumed in the field and partition the field evapotranspiration into maize transpiration and soil evaporation. Such efforts not only contribute to our understanding of the water cycle in SPAC of agroecosystem, but also provide theoretical guidance for water-saving techniques in agriculture. Therefore, the main objectives 
of this study were to (1) estimate field evapotranspiration during different growth stages of maize using a field water balance model; (2) obtain the parameters $\left(\delta_{E T}{ }^{18} \mathrm{O}, \delta_{T}^{18} \mathrm{O}\right.$ and $\left.\delta_{E}{ }^{18} \mathrm{O}\right)$ of the isotope mass balance model and partition field evapotranspiration into maize transpiration and soil evaporation during different growth stages.

\section{Materials and methods}

\subsection{Study site description}

Field experiments were conducted at the Agro-ecological Experimental Station of the Chinese Academy of Sciences in Fengqiu, Henan Province, located in the Huang-Huai-Hai Plain in north China $\left(35^{\circ} 01^{\prime} \mathrm{N}, 114^{\circ} 24^{\prime} \mathrm{E}\right)$. The study area is located in a temperate zone and has a semi-humid monsoon climate. The annual precipitation in the area is approximately $615 \mathrm{~mm}, 60-90 \%$ of which occurs from May to October, and the average annual temperature in the area is $13.9^{\circ} \mathrm{C}$. The soil type is fluvo-aquic soil and the profiles generally consist of three layers, with sandy loam being present at depths of 0-30 cm, silty clay being present at 30-60 cm, and sandy loam being present at $60-170 \mathrm{~cm}$. Some basic physical and chemical properties of the soil are listed in Table 1 . All soil properties were determined following standard methods as indicated in the footnote of Table 1.

\subsection{Field experimental design}

Experimental plots were established in the station with three replicates. Each plot measured $8 \times 6 \mathrm{~m}$ and was separated by concrete walls that were inserted into the soil to a depth of $0.8 \mathrm{~m}$, with $0.2 \mathrm{~m}$ remaining above the soil surface. Maize was seeded on June 5, 2007 and harvested on September 12, 2007. According to local practice, $190 \mathrm{~kg} \mathrm{ha}^{-1} \mathrm{~N}$ (as urea), $80 \mathrm{~kg} \mathrm{ha}^{-1} \mathrm{P}_{2} \mathrm{O}_{5}$ (as [Ca $\left.\left(\mathrm{H}_{2} \mathrm{PO}_{4}\right)_{2}\right]$ with $\left.46 \% \mathrm{P}_{2} \mathrm{O}_{5}\right)$ and $200 \mathrm{~kg} \mathrm{ha}^{-1} \mathrm{~K}_{2} \mathrm{O}($ as $\mathrm{K}_{2} \mathrm{SO} 4$ with $50 \% \mathrm{~K}_{2} \mathrm{O}$ ) were applied. Nitrogen fertilizer was split broadcast, with $40 \%$ being applied as basal fertilizer before seeding and the rest being applied at booting. The other fertilizers mentioned above were applied completely as basal fertilizers. The growth stages of seedling, jointing, booting, tasseling, and filling were started on June 14, July 12, July 22, August 2 and August 20, respectively. The variety of maize grown was Zhengdan 958 and its population was about 62,500 plants per hectare.

A PVC (Polyvinyl Chloride) tube with a diameter of $5 \mathrm{~cm}$ was installed in the center of one plot to a depth of 8 $\mathrm{m}$ and used for groundwater monitoring every 5 days. A plastic cap was used to cover the tube after observation to avoid contamination. Soil volumetric water content was measured at 17 depths (every $10 \mathrm{~cm}$ from soil surface to $170 \mathrm{~cm}$ depth) at 5 days intervals in each plot using neutron soil moisture probe (CNC 503, produced by Beijing Chaoneng Technology Co. LTD). Soil water potential was measured by Portable SM-1 type of soil water potentiometer (Xin et al., 2007) at the five depths $(20,40,80,170$ and $190 \mathrm{~cm}$ ) for every 5 days. In addition, both of soil volumetric water content and soil water potential were measured again when rainfall events happened. Two ceramic suction cups were installed in each plot at the depths of 20 and $40 \mathrm{~cm}$ to extract soil water of different layers. Finally, meteorological data was obtained from a weather station located 10 meters east of the study field on a daily basis.

\subsection{Water balance model in the field}

A field water balance model was used to calculate field evapotranspiration (ET):

ET $=$ Precipitation - Soil water variety - Runoff - Crop interception- Infiltration + Capillary rise

where precipitation was obtained from the weather station; soil water variety was calculated from the observation results of soil volumetric water content; runoff and crop interception were ignored; and infiltration or capillary rise were estimated through soil water flow flux $(q)$ and water flow direction (up or down), which were determined by water potential measured by soil water potentiometer. Water flow flux $q$ was calculated using Darcy's Law:

$$
q=-K \times(d \varphi / d D)
$$

where $K$ was the unsaturated hydraulic conductivity which depended on soil volumetric water content or soil water potential; $\varphi$ was soil water potential which was measured by portable SM-1 type of soil water potentiometer; $D$ was the distance. $K$ was obtained through van Genuchten-Mualem model:

$$
\begin{gathered}
K=K_{\mathrm{s}} S^{0.5}\left(1-\left(1-S^{1 / \mathrm{m}}\right)^{\mathrm{m}}\right)^{2} \\
S=\left(\theta-\theta_{r}\right) /\left(\theta_{s}-\theta_{r}\right)
\end{gathered}
$$

where $K_{s}$ was saturated hydraulic conductivity; $S$ was saturation; $\theta$ was soil volumetric water content, $\theta_{r}$ and $\theta_{s}$ were the soil residual and saturated volumetric water contents, respectively, $m$ was a parameter relating to the shape of soil water retention curve (Li. et $a l, 2007)$. $\theta$ was measured by neutron soil moisture probe, $\theta_{s}$ was 
shown in Table 1, $\theta_{r}$ and $m$ were estimated by pedo-transfer functions as the research of Li which was conducted in the same study area (Li. et al. 2007).

When calculating field evapotranspiration with the water balance model, we supposed that infiltration or capillary rise water boundary was the groundwater table. If the groundwater table was deeper than $1.7 \mathrm{~m}$, the boundary was fixed at $1.7 \mathrm{~m}$ depth.

\subsection{Sampling for stable isotope analysis}

During each growth stage, we installed an airtight flexible cylindrical tube in the water outlet of a dehumidifier (Super dehumidifier MDH-616A, Morii, Japan), and the tube was inserted into an airtight bottle to collect air vapor in the field. Transpired water from maize leaf was collected directly through an airproof bag which was covered around the leaves tightly as described by Yakir et al. (1993). Soil water at the surface of $20 \mathrm{~cm}$ and the depths of 20 40 were extracted using ceramic suction cups under $-0.85 \mathrm{kPa}$ after 12 hours of equilibrium in each plot. The above water samples were collected during each growth stage on June 24, July 17, July 30, August 18 and September 2, respectively. During each rain event, rainwater was collected in the field using rain gauges that contained paraffin oil (at least $2 \mathrm{~mm}$ ) to prevent evaporation (Dodd et al., 1998). When rain events lasted for several days, the rainwater was collected every day to eliminate the potential evaporation.

All of the water samples were collected with three replication, and then transferred into airtight bottles immediately upon collection and stored in the laboratory at -20 until isotopic analysis.

\subsection{Sable oxygen isotope analysis}

In this study, the oxygen isotope ratios were analyzed by the $\mathrm{CO}_{2}$ equilibration method (Scoki et al., 1999) using $2 \mathrm{ml}$ water samples that were equilibrated with $\mathrm{CO}_{2}$ overnight at 25 . The stable oxygen isotope in the treated samples were analyzed using a MAT253 isotope ratio mass spectrometer (Thermo Finnigan America).

Isotope composition is usually expressed as the molar ratio of heavier to lighter isotopes $(R)$, whereas the absolute quantity of stable isotopes in nature is extremely low. For convenience, $R$ is generally converted to values of $\delta$ (stable isotope composition),

$$
\delta(\%)=(R(\text { sample }) / R(\text { standard })-1) \times 1000
$$

where $R$ (sample) and $R$ (standard) are the molar ratios of the heavier and lighter isotope of the sample and the standard, respectively. The standard in this study was V-SMOW (Vienna standard mean ocean water). The analytical precision was $0.1 \%$ and the accuracy was better than $0.1 \%$ for $\delta^{18} \mathrm{O}$.

\subsection{Methods for obtaining parameters of isotope mass balance model}

The isotope mass balance model could be expressed as:

$$
\begin{gathered}
\delta_{E T}^{18} \mathrm{O}=F_{E} \delta_{E T}^{18} \mathrm{O}+F_{T} \delta_{T}^{18} \mathrm{O} \\
F_{E}+F_{T}=1
\end{gathered}
$$

where $F_{E}$ and $F_{T}$ were the fraction of soil evaporation and plant transpiration in the field evapotranspiration, respectively; the others symbols were the same as described above.

$E T$ could be estimated through the field water balance model, $\delta_{\mathrm{T}}{ }^{18} \mathrm{O}$ was measured from the transpired water directly (Harwood et al., 1998), $\delta_{\mathrm{E}}{ }^{18} \mathrm{O}$ was transformed from $R_{\mathrm{E}}{ }^{18} \mathrm{O}$ according to the Eq. (7), and $R_{\mathrm{E}}{ }^{18} \mathrm{O}$ was calculated by the following equation (Moreira et al., 1997; Yepez et al., 2003):

$$
R_{\mathrm{E}}{ }^{18} \mathrm{O}=\left(1 / \alpha_{K}\right) \times\left(R_{\mathrm{S}}{ }^{18} \mathrm{O} / \alpha_{e q}-R_{\mathrm{a}}{ }^{18} \mathrm{O} \times h\right) /(1-h)
$$

where $R_{\mathrm{E}}{ }^{18} \mathrm{O}, R_{\mathrm{S}}{ }^{18} \mathrm{O}, R_{\mathrm{a}}{ }^{18} \mathrm{O}$ were the molar ratio of heavier to lighter isotope of evaporation water from soil surface, soil water at the evaporation surface, and air vapor, respectively; $h$ was the atmospheric relative humidity and could be obtained from the weather station; $\alpha_{K}$ was the kinetic fractionation factor which depended on the differences in reaction rates and diffusion coefficients of isotope molecules in air, and would be higher values for diffusive and lower values for turbulent boundary layers (Moreira et al., 1997; Yepez et al., 2003; Yakir \& Sternberg, 2000), here we selected 1.0285 for oxygen; $\alpha_{e q}$ was the oxygen equilibrium fractionation factor for two phases of liquid water and vapor which was the function of temperature, and could be expressed as follows (Yepez et al., 2003):

$$
\alpha_{e q}^{18} \mathrm{O}=\left(1.137\left(10^{6} / \mathrm{T}^{2}\right)-0.4156\left(10^{3} / \mathrm{T}\right)-2.0667\right) / 1000+1
$$

where $\mathrm{T}$ was the soil temperature in $\mathrm{K}$.

We applied a simple isotope mass balance model in the top surface $20 \mathrm{~cm}$ soil to estimate the $\delta_{\mathrm{ET}}{ }^{18} \mathrm{O}$ (Hsieh et al., 1998; Ferretti et al., 2003). During each growth stage: 


$$
\begin{gathered}
m_{\text {initial }}+m_{P}+m_{\text {rise }}=m_{\text {final }}+m_{E T}+m_{\text {infiltration }} \\
\delta_{\text {initial }}{ }^{18} \mathrm{O} m_{\text {initial }}+\delta_{P}{ }^{18} \mathrm{O} m_{P}+\delta_{\text {rise }}{ }^{18} \mathrm{O} m_{\text {rise }}=\delta_{\text {final }}{ }^{18} \mathrm{O} m_{\text {final }}+\delta_{E T}{ }^{18} \mathrm{O} m_{E T}+\delta_{\text {infiltration }}{ }^{18} \mathrm{O} m_{\text {infiltration }}
\end{gathered}
$$

where $m$ referred to the mass of water (presented as $\mathrm{mm}$ ) and $\delta^{18} \mathrm{O}$ represented the oxygen isotope composition of each component. The subscripts of initial, final, rise, infiltration, $P$ and ET, represented water in the initial soil, final soil, capillary rise, infiltration, precipitation, and evapotranspiration during each growth stage, respectively. Sampling date was determined by the maize growth stage, which was the final sampling date of the prior stage, and the initial date of the next stage.

Values of $m_{\text {initial }}$ and $m_{\text {final }}$ were measured by neutron soil moisture probe, $m_{P}$ was observed in the weather station, and $m_{E T}$ was obtained by the water balance model (Eq.3), then $m_{\text {rise }}$ or $m_{\text {infiltration }}$ could be obtained through equation (12). $\delta_{\text {initial }}{ }^{18} \mathrm{O}$ and $\delta_{\text {final }}{ }^{18} \mathrm{O}$ were the isotope composition of the top surface $20 \mathrm{~cm}$ soil water.

$\delta_{P}{ }^{18} \mathrm{O}$ was the precipitation isotope composition which was weighted for each rainfall, if there were rainfall events more than one time in some growth stages (determined by multiplying the isotopic composition by precipitation of each time and dividing by the total precipitation), and which was expressed as follows:

$$
\delta_{P}{ }^{18} \mathrm{O}=\sum\left(P_{i} \delta_{P i}{ }^{18} \mathrm{O}\right) / m_{P}
$$

where $P_{i}$ was the rainfall for each rainfall event and $\delta_{P}{ }^{18} \mathrm{O}$ was its isotope composition, the others symbols means were the same as mentioned above.

We assumed that the top surface $20 \mathrm{~cm}$ soil couldn't retain the precipitation and formed infiltration when heavy rainfall made soil water content excess field moisture capacity, and thus $\delta_{\text {infiltration }}{ }^{18} \mathrm{O}$ was given as:

$$
\delta_{\text {infiltration }}{ }^{18} \mathrm{O}=\sum\left(P_{j}+S_{j}-S_{c}\right) \delta_{P j}{ }^{18} \mathrm{O} / m_{\text {infiltration }}
$$

where $S_{c}$ was the field moisture capacity (Table 1), $P_{j}$ was the rainfall for each heavy rainfall which leaded to infiltration and $\delta_{P j}{ }^{18} \mathrm{O}$ was its isotope composition, $S_{j}$ was the soil water content before the precipitation. Eq.(15) would only been established when the value $\left(P_{j}+S_{j}\right)$ was greater than $S_{c}$.

If the next layer water rose up to the top $20 \mathrm{~cm}, \delta_{\text {rise }}{ }^{18} \mathrm{O}$ was the water in $20 \sim 40 \mathrm{~cm}$ depth. Substituted these parameters into equation (13) and $\delta_{E T}^{18} \mathrm{O}$ of each growth stage could be calculated.

After we obtained $\delta_{E}{ }^{18} \mathrm{O}$ and $\delta_{T}{ }^{18} \mathrm{O}$, and then substituted $\delta_{E}{ }^{18} \mathrm{O}, \delta_{T}{ }^{18} \mathrm{O}$ and $\delta_{E T}{ }^{18} \mathrm{O}$ in to Eqs. (8) and (9), the fraction of transpiration in the field evapotranspiration was,

$$
F_{T}=\left(\delta_{E}{ }^{18} \mathrm{O}-\delta_{E T}{ }^{18} \mathrm{O}\right) /\left(\delta_{E}{ }^{18} \mathrm{O}-\delta_{T}{ }^{18} \mathrm{O}\right)
$$

\section{Results and discussion}

\subsection{Rainfall, groundwater table, soil volumetric water content and soil water potential during different growth} stages of maize

The total rainfall was $427.4 \mathrm{~mm}$ and the daily rainfall during the maize growth period was shown in Fig.1. The experimental station was located approximately $15 \mathrm{~km}$ from the Yellow River, where the groundwater table varied greatly with seasons (rain season and dry season) and the Yellow River flood season. The groundwater table gradually increased from June 14 (seedling) to August 4 (tasseling), ranging from $4.2 \mathrm{~m}$ to $1.09 \mathrm{~m}$ below the ground, while it fluctuated between $1.95 \mathrm{~m}$ and $0.95 \mathrm{~m}$ in the subsequent growth stages.

Similar to the groundwater table, the soil volumetric water content increased throughout the entire maize growth period, although it varied slightly between jointing and booting (Fig.2). The spatial distribution of the soil volumetric water content in the profile from the surface to $1.7 \mathrm{~m}$ was more complicated than the temporal distribution. Specifically, the soil volumetric water content increased continually from $20 \mathrm{~cm}$ to $80 \mathrm{~cm}$ over the growth period, although it showed a decrease of about $1 \mathrm{~m}$ depth during the seedling, jointing and booting stages. This was likely because the rainy season began in May and rain water primarily replenished the upper soil water, but did not reach below $1 \mathrm{~m}$ depth during the three previous growth stages. From tasseling to filling, the soil water content at depths of 20 and $40 \mathrm{~cm}$ was usually lower than $0.3 \mathrm{~m}^{3} \mathrm{~m}^{-3}$. Groundwater was usually greater than $1.7 \mathrm{~m}$ during tasseling (Fig.1), which lead to saturated soils at this depth and little variation during this period (data not shown, Fig.2 only shows the soil volumetric water content on the soil water sampling day).

The soil water potential increased continually from the time of planting and presented a wave-shape during the tasseling stage (Fig.3). From seedling to booting, the soil water potential at 20 and $40 \mathrm{~cm}$ depths increased slightly when compared to the potential at $80 \mathrm{~cm}$ depth. During tasseling and filling, the soil water potentials at depths of 20 and $40 \mathrm{~cm}$ were lower than at depth of $80 \mathrm{~cm}$. The lowest soil water potential in seedling, jointing and booting was the interface of silt clay and sandy loam at the depth of $0.8 \mathrm{~m}$ (Table 1), and exhibited the highest value in $1.9 \mathrm{~m}$ depth from tasseling to mature (Fig.3). 


\subsection{Field evapotranspiration during different growth stages}

The components of water balance model (evapotranspiration, precipitation, infiltration or capillary rise, and variety of soil water) were shown in Table 2, which showed that infiltration and capillary rise reached lowest in the stage of filling-mature and booting, respectively, while reached greatest during the stage of booting and filling-mature, and soil water variation fluctuated from $-11.1 \mathrm{~mm}$ (negative sign represent the soil water decreased when compared to the prior growth stage) in booting to $19.1 \mathrm{~mm}$ in seedling. Field evapotranspiration was $481.8 \mathrm{~mm}$, and precipitation occupied most of the field evapotranspiration during the maize growth period.

\subsection{Partitioning evapotranspiration into maize transpiration and soil evaporation}

Soil water sampling date and the parameters used in Eq.(10) for $\delta_{\mathrm{E}}{ }^{18} \mathrm{O}$ estimation were listed in Table 3. On account of water infiltration and capillary rise, the parameters used to estimated $\delta_{\mathrm{ET}}{ }^{18} \mathrm{O}$ with Eqs.(12) and (13)were showed in Table 4. Values of $\delta_{\mathrm{E}}{ }^{18} \mathrm{O}$ and $\delta_{\mathrm{ET}}{ }^{18} \mathrm{O}$ for each growth stage were substituted in Eqs.(8) and (9), $F_{T}$ was worked out and was shown in Table 5 . The ratio of maize transpiration to field evapotranspiration during the stages of seedling, jointing, booting, tasseling, and filling-mature were $11.8 \%, 65.0 \%, 78.3 \%, 81.5 \%$, $50 \%$, respectively, The maize transpiration and soil evaporation of the whole growth period were $252.4 \mathrm{~mm}$ and $229.4 \mathrm{~mm}$, and took up $52.4 \%$ and $47.6 \%$ of the water consumed by the whole field evapotranspiration, respectively. Water consumed by transpiration distributed in the stage of seedling, jointing, booting, tasseling, and filling-mature were $14.5,53.2,64.6,58.5$, and $61.6 \mathrm{~mm}$, respectively, accordingly, the distribution of soil evaporation in the five growth stages were 108.3, 28.7, 17.9, 13.0, and $61.6 \mathrm{~mm}$, respectively.

\subsection{Water dynamic in field during maize growing period}

High precipitation(annual average was about $615 \mathrm{~mm}$ and $427.4 \mathrm{~mm}$ distributed in the period of maize growing), groundwater table and evapotranspiration during maize growing period leaded to water transport frequently in soil in the study area and produced obvious effect on soil water potential and soil volumetric water content.

Water flow direction in soil was determined by the soil water potential and flow from the high potential position to the low potential position. The variation of soil water potential in profile indicated that infiltration and capillary rise water were indeed existed during the maize growth period (Fig.3). Before July 29 (in booting), the groundwater table was lower than $1.7 \mathrm{~m}$. The value of soil water potential gradient between 1.7 and $1.9 \mathrm{~m}$ depth was various and leaded to infiltration or capillary rise took place between soil and groundwater; the soil water potential at $0.8 \mathrm{~m}$ was lowest from June 14(in seedling) to July 29(in booting), and the water above and underside would flow to this layer, and leaded soil volumetric water content of this layer increased (Fig.2). Obviously, field evapotranspiration in this period mainly came from the soil water above $0.8 \mathrm{~m}$ and precipitation. From July 29(in booting) to maize mature, the soil water potential gradually increased with depth, and main water flow in soil was capillary rise (Fig.3).

Water lost in seedling was mainly from soil evaporation, and the proportion of water consumed by maize transpiration in the evapotranspiration apparently increased from seedling to tasseling, and took up most of field evapotranspiration in jointing, booting, and tasseling, then decreased from filling to mature. The similar trend was also reported by Kang et al. (2003) based on a study in a semi-arid region of northwest China $\left(34^{\circ} 20^{\prime} \mathrm{N}\right.$, $108^{\circ} 24^{\prime} \mathrm{E}$ ), and which could provide an indirect confirmation that the calculation results of isotope mass balance model was accurate.

\subsection{Advantages of the isotope mass balance model}

The estimation of the parameters $\delta_{\mathrm{ET}}{ }^{18} \mathrm{O}$ in Eq. (8) was important when stable oxygen isotope was applied in water flux studies in terrestrial ecosystems. Most of present researchers used Keeling plot to estimate $\delta_{\mathrm{ET}}{ }^{18} \mathrm{O}$ (Bowling et al. 2001; KÖhler et al., 2006), since it was founded by Keeling (1960) based on mass conservation principle during the exchange of water between two reservoirs. Application of keeling plot in a given ecosystem (such as agroecosystem) was expressed as follows:

$$
\begin{aligned}
C_{\text {new }} & =C_{a}+C_{\text {add }} \\
C_{\text {new }} \delta_{\text {new }}{ }^{18} \mathrm{O} & =C_{a} \delta_{a}{ }^{18} \mathrm{O}+C_{\text {add }} \delta_{\text {add }}{ }^{18} \mathrm{O}
\end{aligned}
$$

where $C_{\text {new }}, C_{a}$ and $C_{a d d}$ were the concentrations of the $\mathrm{H}_{2} \mathrm{O}$ in the given ecosystem, in the atmosphere and that added component to this ecosystem, respectively; $\delta_{\mathrm{x}}{ }^{18} \mathrm{O}$ represented the stable oxygen isotopic composition of the component $\mathrm{x}$.

Combining Eqs.(17) and (18), we got the equation (19),

$$
\delta_{\text {new }}{ }^{18} \mathrm{O}=C_{a}\left(\delta_{a}{ }^{18} \mathrm{O}-\delta_{\text {add }}{ }^{18} \mathrm{O}\right)\left(1 / C_{\text {new }}\right)+\delta_{\text {add }}{ }^{18} \mathrm{O}
$$


This was a linear relationship of $\delta_{\text {new }}{ }^{18} \mathrm{O}$ versus the inverse of its concentration with a slope of $C_{a}\left(\delta_{a}{ }^{18} \mathrm{O}-\right.$ $\delta_{\text {add }}^{18} \mathrm{O}$ ), and an intercept at the value of $\delta_{\text {add }}^{18} \mathrm{O}$.

There were three basic limitations when Keeling plot was applied in the studies of water flux: (1) the ecosystem consisted of only two reservoirs; (2) the isotope ratio of the added reservoir did not change during the experimental period. However, If the added ecosystem component was composed of several different sources or sinks (KÖhler et al., 2006), from Eq.(19), the Keeling plot still could be used as long as the relative contribution of each of these subcomponents remained fixed (Yakir and Sternberg, 2000); (3) A series of data of the vapor concentration $\left(C_{n e w}\right)$ and its oxygen isotope composition $\left(\delta_{\text {new }}{ }^{18} \mathrm{O}\right)$ in the given ecosystem should present some differences during the experiment time, and thus ensured the Eq.(19) could be obtained. This condition was easy to satisfy in a closed ecosystem but was difficult to realize in an open ecosystem. Otherwise, if $C_{\text {new }}$ and $\delta_{\text {new }}{ }^{18} \mathrm{O}$ varied with height and could be measured, the Keeling plot could also be used to estimate $\delta_{E T}{ }^{18} \mathrm{O}$, and which was adapted well to forest ecosystem with high trees, but which was also difficult to fulfill in an agroecosystem with maize grown. Therefore, we used a simple isotope mass balance model to determine $\delta_{E T}{ }^{18} \mathrm{O}$ during each maize growth stages, and still considered the effect of infiltration or capillary rise, and made sure the calculated results was more exact.

\section{Conclusions}

In this study, an isotope mass balance model was used to partition field evapotranspiration into maize transpiration and soil evaporation during different growth stages. The methods for obtaining the parameters of $\delta_{E T}{ }^{18} \mathrm{O}, \delta_{T}{ }^{18} \mathrm{O}$ and $\delta_{T}{ }^{18} \mathrm{O}$ could overcome the limitations of Keeling Plot which had been widely used in water flux studies in terrestrial ecosystems. And we consider the methods in this study are not only able to partition field evapotranspiration into plant transpiration and soil evaporation in agroecosystem, but also can be applied to research water cycle in other ecosystem, such as forest, grassland and desert ecosystems.

\section{References}

Allen, L.H., Pan, D.Y., Boote, K.J., Pickering, N.B. \& Joes, J.W. (2003). Carbon dioxide and temperature effects on evapotranspiration and water use efficiency of soybean. Agron J., 95, 1071-1081. http://dx.doi.org/10.2134/agronj2003.1071

Baldocchi, D.D., Hicks, B.B. \& Meyers, T.P. (1988). Measuring biosphere-atmosphere exchanges of biologically related gases with micrometeorological methods. Ecology, 69, 1331-1340. http://dx.doi.org/10.2307/1941631

Bowling, D.R., Tans, P.P. \& Monson, R.K. (2001). Partitioning net ecosystem carbon exchange with isotope fluxes of $\mathrm{CO}_{2}$. Glob. Change Biol., 7, 127-145. http://dx.doi.org/10.1046/j.1365-2486.2001.00400.x

CRISO. (1988). CSIRO disc permeameter instruction manual. CRISO Center for Environmental Mathematics, Canberra, Australia.

Dodd, M.B., Lauenroth, W.K. \& Welker, J.M. (1998). Differential water resource use by herbaceous and wood plant life-forms in a shortg, rass steppe community. Oecologia, 117, 504-512. http://dx.doi.org/10.1007/s004420050686

Ferretti, D.F., Pendall, E., Morgan, J.A., Nelson, J.A., LeCain, D. \& Mosier, A.R. (2003). Partitioning evapotranspiration fluxes from a Colorado grassland using stable isotopes: Seasonal variations and ecosystem implications of elevated atmospheric $\mathrm{CO}_{2}$. Plant Soil, 254, 291-303. http://dx.doi.org/10.1023/A:1025511618571

Flanagan, L.B., Comstock, J.P. \& Ehleringer, J.R. (1991). Composition of modeled and observed environmental influences on the stable oxygen and hydrogen isotope composition of leaf water in Phaseolus vulgaris L. Plant Physiol., 96, 588-596. http://dx.doi.org/10.1104/pp.96.2.588

Harwood, K.G., Gillon, J.S., Griffiths, H. \& Broadmeadow, S.J. (1998). Diurnal variation of $\Delta^{13} \mathrm{CO}_{2}, \Delta \mathrm{C}^{18} \mathrm{O}^{16} \mathrm{O}$ and evaporative site enrichment of $\delta \mathrm{H}_{2}{ }^{18} \mathrm{O}$ in Piper aduncum under field conditions in Trinidad. Plant Cell Environ., 21, 269-283. http://dx.doi.org/10.1046/j.1365-3040.1998.00276.x

Hsieh, J.C.C., Chadwick, O.A., Kelly, E.F. \& Savin, S.M. (1998). Oxygen isotopic composition of soil water: Implications for partitioning evapotranspiration. Geoderma, 82, 269-293, http://dx.doi.org/10.1016/S0016-7061(97)00105-5

ISSCAS. (1978a). Methods of analysis on soil physical and chemical properties (ed. ISSCAS). Shanghai Science \& Technology Press, Shanghai (In Chinese), 466-535. 
ISSCAS. (1978b). Methods of analysis on soil physical and chemical properties (ed. ISSCAS). Shanghai Science \& Technology Press, Shanghai (In Chinese), 448-450.

Jarvis, P.G. (1995). Scaling processes and problems. Plant Cell Environ., 18, 1079-1089. http://dx.doi.org/10.1111/j.1365-3040.1995.tb00620.x

Kang, S.Z., Gu, B.J., Du, T.S. \& Zhang, J.H. (2003). Crop coefficient and ratio of transpiration to evapotranspiration of winter wheat and maize in a semi-humid region. Agricul. Water Manage., 59, 239-254. http://dx.doi.org/10.1016/S0378-3774(02)00150-6

Keeling, C.D. (1960). The concentration and isotope abundance of carbon dioxide in the atmosphere. Tellus, 2, 199-203. http://dx.doi.org/10.1111/j.2153-3490.1960.tb01300.x

KÖhler, P., Fischer, H., Schmitt, J. \& Munhoven, G. (2006). On the application and interpretation of Keeling plots in paleo climate research - deciphering $\delta^{13} \mathrm{C}$ of atmospheric $\mathrm{CO}_{2}$ measured in ice cores. Biogeosciences, 3 , 539-556. http://www.biogeosciences.net/3/539/2006

Li, C. (1999). Carbon isotope composition, water-use efficiency and biomass productivity of Eucalyptus microtheca populations under different water supplies. Plant Soil, 214, 165-171. http://dx.doi.org/10.1023/A:1004708815973

Li, Y., Chen, D., White, R.E., Zhu, A. \& Zhang, J. (2007). Estimating soil hydraulic properties of Fengqiu County soils in the North China Plain using pedo-transfer functions. Geoderma, 138, 261-271. http://dx.doi.org/10.1016/j.geoderma.2006.11.018

Moreira, M.Z., Martinell, L.A., Victoria, R.L., Barbosa, E.M., Bonates, L.C.M., \& Nepstads, D.C. (1997). Contribution of transpiration to forest ambient vapour based on isotopic measurements. Glob Change Biol., 3, 439-450. http://dx.doi.org/10.1046/j.1365-2486.1997.00082.x

Paco, T.A., Ferreira, M.I., \& Conceiçäo, N. (2006). Peach orchard evapotranspiration in a sandy soil: Comparison between eddy covariance measurements and estimates by the FAO 56 approach. Agr. Water Manage., 85, 305-313. http://dx.doi.org/10.1016/j.agwat.2006.05.014

Philip, J.R. (1966). Plant water relations: Some physical aspects. Annu. Rev. Plant Physiol., 17, 245-268, http://dx.doi.org/10.1146/annurev.pp.17.060166.001333

Scoki, R.A., Romanek, C.S. \& Gibson, Jr. E.K. (1999). On-line technique for measuring stable oxygen and hydrogen isotopes from microliter quantities of water. Anal. Chem., 71, 2250-2253. http://dx.doi.org/10.1021/ac981140i

Scott, R.L., Watts, C., Payan, J.G., Edwards, E., Goodrich, D.C., Williams, D. \& Shuttleworth, W.J. (2003). The understory and overstory partitioning of energy and water fluxes in an open canpy, semiarid woodland. Agri. Forest Meteorol., 114, 127-139. http://dx.doi.org/10.1016/S0168-1923(02)00197-1

Steinwand, A.L., Harringtong, R.F. \& Or, D. (2006). Water balance for great basin phreatophytes derived from eddy covariance, soil water, and water table measurements. J. Hydrol., 329, 595-605. http://dx.doi.org/10.1016/j.jhydrol.2006.03.013

Sun, G., Noormets, A., Chen, J. \& McNulty, S.G. (2008). Evapotranspiration estimates from eddy covariance towers and hydrologic modeling in managed forests in Northern Wisconsin, USA. Agri. Forest Meteorol., 148, 257-267. http://dx.doi.org/10.1016/j.agrformet.2007.08.010

Vaughan, P.J., Trout, T.J. \& Aars, J.E. (2007). A processing method for weighing lysimeter data and comparison to micrometeorological ETo predictions. Agr. Water Manage., 88, 141-146. http://dx.doi.org/10.1016/j.agwat.2006.10.008

Williams, D.G., Cable, W., Hultine, K., Hoedjes, J.C.B., Yepez, E.A., Simonneaux ,V., Er-Raki, S., Boulet, G., de Bruin, H.A.R., Chehbouni, A., Hartogensis, O.K. \& Timouk, F. (2004). Evapotranspiration components determined by stable isotope, sap flow and eddy covariance techniques. Agri. Forest Meteorol., 125, 241-258. http://dx.doi.org/10.1016/j.agrformet.2004.04.008

Wilson, K.B., Hanson, P.J. \& Mulholland, P.J. (2001). A comparison of methods for determining forest evapotranspiration and its components: sap-flow, soil water budget, eddy covariance and catchment water balance. Agri. Forest Meteorol., 106, 153-168. http://dx.doi.org/10.1016/S0168-1923(00)00199-4

Xin, X.L., Xu, F.A., Zhang, J.B. \& Xu, M.X. (2007). A new resistance sensor for monitoring soil matric potential. Soil Sci. Soc. Am. J., 71, 866-871. http://dx.doi.org/10.2136/sssaj2006.0195 
Yakir, D., Berry, J.A., Giles, L. \& Osmond, C.B. (1993). The ${ }^{18} \mathrm{O}$ of water in the metabolic compartment of transpiring leaves. In: Ehleringer, J., Hall, A. \& Farqubar, G. (eds.). Stable Isotopes and Plant Carbon-Water Relations (pp 511-527). New York: Academic Press Inc.

Yakir, D. \& Sternberg, L.daS.L. (2000). The use of stable isotopes to study ecosystem gas exchange. Oecologia. 123, 297-311. http://dx.doi.org/10.1007/s004420051016

Yepez, E.A., Williams, D.G., Scott, R.L. \& Lin, G. (2003). Partitioning overstory and understory evapotranspiration in a semiarid savanna woodland from the isotopic composition of water vapor. Agr. Forest Meteorol., 119, 53-68. http://dx.doi.org/10.1016/S0168-1923(03)00116-3.

Zhao, B., Kondo, M., Maeda, M., Ozaki, Y. \& Zhang, J. (2004). Water-use efficiency and carbon isotope discrimination in two cultivars of upland rice during different developmental stages under three water regimes. Plant Soil, 261, 61-75. http://dx.doi.org/10.1023/B:PLSO.0000035562.79099.55

Table 1 . Some physical and chemical properties of the soil in the study area

\begin{tabular}{|l|l|l|l|l|l|l|l|l|l|l|}
\hline \multirow{2}{*}{$\begin{array}{l}\text { Depth } \\
/ \mathrm{cm}\end{array}$} & $\begin{array}{l}\text { Soil } \\
\text { texture }\end{array}$ & Sand & Silt & Clay & $\begin{array}{l}\text { Organic } \\
\mathrm{C}^{\mathrm{b}} / \mathrm{g} \\
\mathrm{kg}^{-1}\end{array}$ & $\begin{array}{l}\text { Bulk } \\
\text { density } \\
/ \mathrm{g} \mathrm{cm}^{-3}\end{array}$ & $\begin{array}{l}\text { Electric } \\
\text { conductivity } \\
/ \mu \mathrm{S} \mathrm{cm}^{-1}\end{array}$ & $\begin{array}{l}\text { Field } \\
\text { moisture } \\
\text { capacity }^{\mathrm{e}} \\
/ \mathrm{cm}^{3} \mathrm{~cm}^{-3}\end{array}$ & $\begin{array}{l}\text { Saturated } \\
\text { volumetric } \\
\text { water } \\
\text { content }^{\mathrm{f}} \\
/ \mathrm{cm}^{3} \mathrm{~cm}^{-3}\end{array}$ & $\begin{array}{l}\text { Saturated } \\
\text { hydraulic } \\
\text { conductivity }^{\mathrm{g}} \\
/ \mathrm{mm} \mathrm{h}^{-1}\end{array}$ \\
\hline $0-30$ & $\begin{array}{l}\text { Sandy } \\
\text { loam }\end{array}$ & 72.9 & 17.5 & 9.6 & 7.4 & 1.55 & 118.13 & 0.275 & 0.415 & 22.6 \\
\hline $30-80$ & $\begin{array}{l}\text { Silt } \\
\text { Clay }\end{array}$ & 47.0 & 34.5 & 18.5 & 14.3 & 1.41 & 173.67 & 0.280 & 0.475 & 19.3 \\
\hline $80-170$ & $\begin{array}{l}\text { Sandy } \\
\text { loam }\end{array}$ & 62.0 & 28.1 & 9.9 & 3.6 & 1.47 & 186.41 & 0.262 & 0.452 & 18.1 \\
\hline
\end{tabular}

${ }^{\mathrm{a}}$ Particle size: pipette method (ISSCAS, 1978a)

${ }^{\mathrm{b}}$ Organic C: dichromate method (ISSCAS, 1978b)

${ }^{\mathrm{c}}$ Bulk density: cutting ring method (ISSCAS, 1978a)

${ }^{\mathrm{d}}$ Electric conductivity: 1:5 soil to water

${ }^{\mathrm{e}}$ Field moisture capacity: cutting ring method (ISSCAS, 1978a)

${ }^{\mathrm{f}}$ Saturated volumetric water content: cutting ring method (ISSCAS, 1978a)

g Saturated hydraulic conductivity: measured using a CRISO disc permeameter in the field (CRISO, 1988)

Table 2. The components of water balance model (evapotranspiration, precipitation, infiltration or capillary rise, soil water variety) during each growth stage

\begin{tabular}{|c|c|c|c|c|c|c|}
\hline \multirow{2}{*}{ Water(mm) } & \multicolumn{5}{|c|}{ Growth stage } & \multirow{2}{*}{ Total (mm) } \\
\cline { 2 - 6 } & Seedling & Jointing & Booting & Tasseling & Filling-mature & \\
\hline Precipitation & 127 & 70.4 & 115.3 & 61 & 53.7 & 427.4 \\
\hline Infiltration & $5.4(0.3)$ & $9.3(0.5)$ & $42.8(2.6)$ & $28.4(1.4)$ & $2(0.1)$ & 87.9 \\
\hline Capillary rise & $20.1(1.8)$ & $34.7(2.1)$ & 0 & $44.5(2.4)$ & $65.6(3.6)$ & 165.0 \\
\hline Soil water variety & $19.1(1.2)$ & $14.0(1.8)$ & $-11.1(1.3)^{1}$ & $5.5(0.9)$ & $-5.9(0.8)^{\mathrm{a}}$ & 21.66 \\
\hline ET & $122.7(4.8)$ & $81.9(3.2)$ & $82.5(3.1)$ & $71.5(4.4)$ & $123.2(5.4)$ & 481.8 \\
\hline
\end{tabular}

anegative sign represent the soil water decrease; The data in the parentheses referred to the standard deviation 
Table 3. Parameters used to estimate the oxygen isotopic composition of the evaporation water $\left(\delta_{\mathrm{E}}{ }^{18} \mathrm{O}\right)$

\begin{tabular}{|c|c|c|c|c|c|}
\hline \multirow{2}{*}{ Parameters } & \multicolumn{5}{|c|}{ Growth stages } \\
\cline { 2 - 6 } & Seedling & Jointing & Booting & Tasseling & Filling-mature \\
\hline Sampling date & June 24 & July 12 & July 30 & August 18 & September 20 \\
\hline Soil temperature $\left({ }^{\circ} \mathrm{C}\right)$ & $30.2(0.2)$ & $27.8(0.1)$ & $25(0.2)$ & $34(0.2)$ & $32.1(0.2)$ \\
\hline$\alpha_{K}$ & 1.0285 & 1.0285 & 1.0285 & 1.0285 & 1.0285 \\
\hline$\alpha_{e q}$ & 1.00893 & 1.00912 & 1.008718 & 1.00934 & 1.00879 \\
\hline$h(\%)$ & $74(2)$ & $78(3)$ & $82(2)$ & $93(4)$ & $86(2)$ \\
\hline$\delta_{\mathrm{S}}{ }^{18} \mathrm{O}(\%)$ & $-0.7(0.2)$ & $-2.4(0.2)$ & $-3.4(0.2)$ & $-4.2(0.1)$ & $-1.3(0.1)$ \\
\hline$\delta_{\mathrm{a}}{ }^{18} \mathrm{O}(\%)$ & $-20.6(0.5)$ & $-19.1(0.4)$ & $-16.6(0.5)$ & $-14.7(0.4)$ & $-14.5(0.3)$ \\
\hline$\delta_{\mathrm{E}}{ }^{18} \mathrm{O}(\%)$ & $-6.5(0.3)$ & $-12.2(0.3)$ & $-18.8(0.4)$ & $-23.9(0.2)$ & $-9.8(0.3)$ \\
\hline
\end{tabular}

The data in the parentheses referred to the standard deviation; $\alpha_{K}$ was the kinetic fractionation factor; $\alpha_{e q}$ was the oxygen equilibrium fractionation factor; $h$ was the atmospheric relative humidity; $\delta_{\mathrm{E}}{ }^{18} \mathrm{O}, \delta_{\mathrm{S}}{ }^{18} \mathrm{O}, \delta_{\mathrm{a}}{ }^{18} \mathrm{O}$ were the oxygen isotopic composition of evaporation water from soil surface, soil water at the evaporation surface, and air vapor, respectively

Table 4. Parameters used to estimate the oxygen isotopic composition of the evapotranspiration water $\left(\delta_{\mathrm{ET}}{ }^{18} \mathrm{O}\right)$

\begin{tabular}{|l|l|l|l|l|l|}
\hline \multirow{2}{*}{ Parameters } & \multicolumn{5}{l|}{ Growth stage } \\
\cline { 2 - 6 } & Seedling & Jointing & Booting & Tasseling & Filling-mature \\
\hline Sampling date & June 24 & July 12 & July 30 & August 18 & September 20 \\
\hline$m_{\text {initial }}(\mathrm{mm})$ & $2.50(0.08)$ & $2.84(0.05)$ & $3.57(0.11)$ & $2.48(0.03)$ & $3.22(0.07)$ \\
\hline$m_{P}(\mathrm{~mm})$ & 127.0 & 70.4 & 115.3 & 61.0 & 53.7 \\
\hline$m_{\text {final }}(\mathrm{mm})$ & $2.84(0.05)$ & $3.57(0.11)$ & $2.48(0.03)$ & $3.22(0.07)$ & $5.23(0.08)$ \\
\hline$m_{\text {rise }}(\mathrm{mm})$ & $-{ }^{a}$ & $12.23(0.26)$ & - & $11.24(0.14)$ & $71.51(0.47)$ \\
\hline$m_{\mathrm{ET}}(\mathrm{mm})$ & 122.7 & 81.9 & 82.55 & 71.5 & 123.2 \\
\hline$m_{\text {infiltration }}(\mathrm{mm})$ & $3.96(0.15)$ & - & $33.59(0.57)$ & - & - \\
\hline$\delta_{\text {initial }}{ }^{18} \mathrm{O}$ & $-0.5(0.1)$ & $-0.7(0.2)$ & $-2.4(0.2)$ & $-3.4(0.2)$ & $-4.2(0.1)$ \\
\hline$\delta_{\mathrm{P}}{ }^{18} \mathrm{O}$ & $-6.1 \pm 0.3$ & $-7.5 \pm 0.2$ & $-7.2 \pm 0.1$ & $-9.7 \pm 0.2$ & $-5.9 \pm 0.1$ \\
\hline$\delta_{\text {final }}{ }^{18} \mathrm{O}$ & $-0.7(0.2)$ & $-2.4(0.2)$ & $-3.4(0.2)$ & $-4.2(0.1)$ & $-1.3(0.1)$ \\
\hline$\delta_{\text {rise }}{ }^{18} \mathrm{O}$ & - & $-7.1(0.3)$ & - & $-8.2(0.1)$ & $-8.3(0.5)$ \\
\hline$\delta_{\text {infiltration }}{ }^{18} \mathrm{O}$ & $-6.2(0.3)$ & - & $-3.2(0.1)$ & - & - \\
\hline$\delta_{\mathrm{ET}}{ }^{18} \mathrm{O}$ & $-6.1(0.2)$ & $-7.4(0.2)$ & $-8.7(0.1)$ & $-9.5(0.4)$ & $-7.4(0.4)$ \\
\hline
\end{tabular}

acapillary rise and infiltration couldn't be existed simultaneously; The data in the parentheses referred to the standard deviation; $m$ referred to the mass of water (presented as $\mathrm{mm}$ ) and $\delta^{18} \mathrm{O}$ represented the oxygen isotope composition of each component. The subscripts of initial, final, rise, infiltration, $P$ and $E T$, represented water in the initial soil, final soil, capillary rise, infiltration, precipitation, and evapotranspiration during each growth stage, respectively. 
Table 5. Parameters in isotope bass balance model during different growth stages of maize

\begin{tabular}{|l|l|l|l|l|l|l|}
\hline \multirow{2}{*}{ Parameters } & \multicolumn{4}{|l}{ Growth stage } & \multicolumn{4}{l|}{ Total } \\
\cline { 2 - 7 } & Seedling & Jointing & Booting & Tasseling & Filling-mature & \\
\hline$\delta_{T}^{18} \mathrm{O}(\%)$ & $-3.1(0.1)$ & $-4.8(0.1)$ & $-5.9(0.2)$ & $-6.3(0.3)$ & $-5.0(0.1)$ & \\
\hline$\delta_{E}{ }^{18} \mathrm{O}(\%)$ & $-6.5(0.3)$ & $-12.2(0.3)$ & $-18.8(0.4)$ & $-23.9(0.2)$ & $-9.8(0.3)$ & \\
\hline$\delta_{E T}{ }^{18} \mathrm{O}(\%)$ & $-6.1(0.2)$ & $-7.4(0.2)$ & $-8.7(0.1)$ & $-9.5(0.4)$ & $-7.4(0.4)$ & \\
\hline$F_{T}(\%)$ & $11.8(1.5)$ & $65.0(5.4)$ & $78.3(3.0)$ & $81.8(5.8)$ & $50.0(4.3)$ & \\
\hline$T(\mathrm{~mm})$ & $14.5(1.8)$ & $53.2(4.4)$ & $64.6(2.5)$ & $58.5(4.1)$ & $61.6(5.3)$ & $252.4(18.2)$ \\
\hline$E(\mathrm{~mm})$ & $108.2 .0(1.8)$ & $28.7(4.4)$ & $17.9(2.5)$ & $13.0(4.1)$ & $61.6(3.8)$ & $229.4(18.2)$ \\
\hline$E T(\mathrm{~mm})$ & 122.7 & 81.9 & 82.5 & 71.5 & 123.2 & 481.8 \\
\hline
\end{tabular}

The data in the parentheses referred to the standard deviation; $\delta_{\mathrm{ET}}{ }^{18} \mathrm{O}, \delta_{\mathrm{T}}{ }^{18} \mathrm{O}$ and $\delta_{\mathrm{E}}{ }^{18} \mathrm{O}$ were the oxygen isotope composition of evapotranspiration, transpiration, and evaporation water, respectively; $E T, \mathrm{~T}$ and $\mathrm{E}$ were evapotranspiration, maize transpiration, and soil evaporation, respectively; $F_{T}$ was the fraction of plant transpiration in the field evapotranspiration.

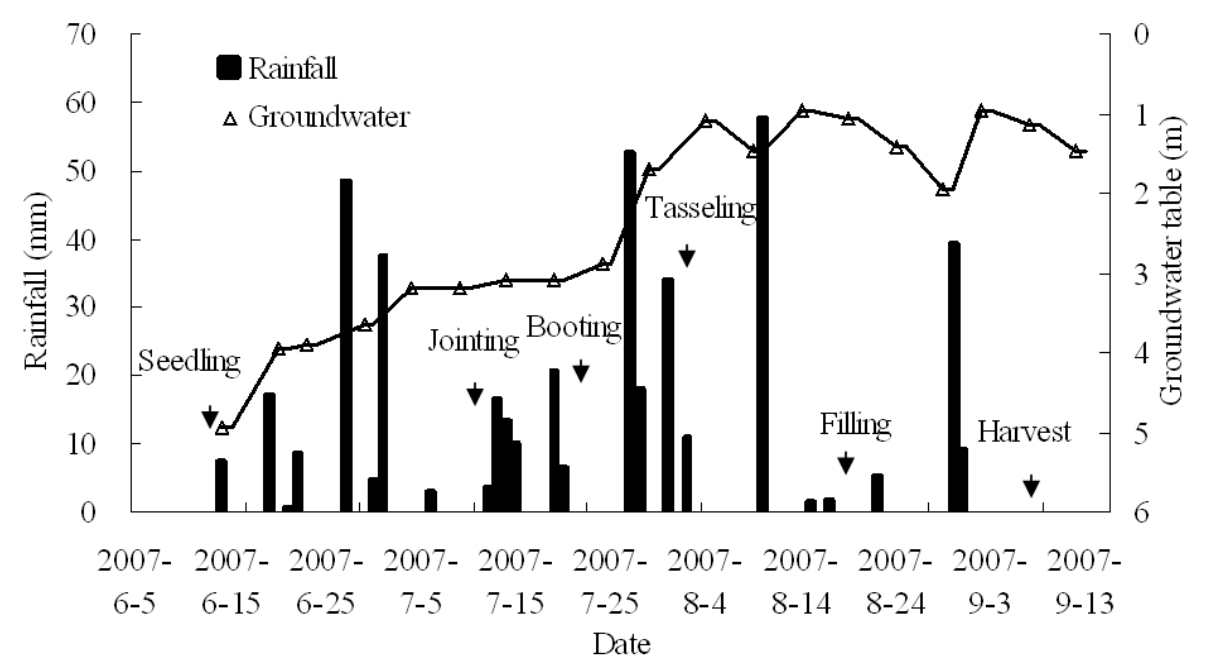

Figure 1. Rainfall distribution and groundwater table variation during the maize growth period (from June 5 to September 12). The arrows indicated the starting date of each growth stage

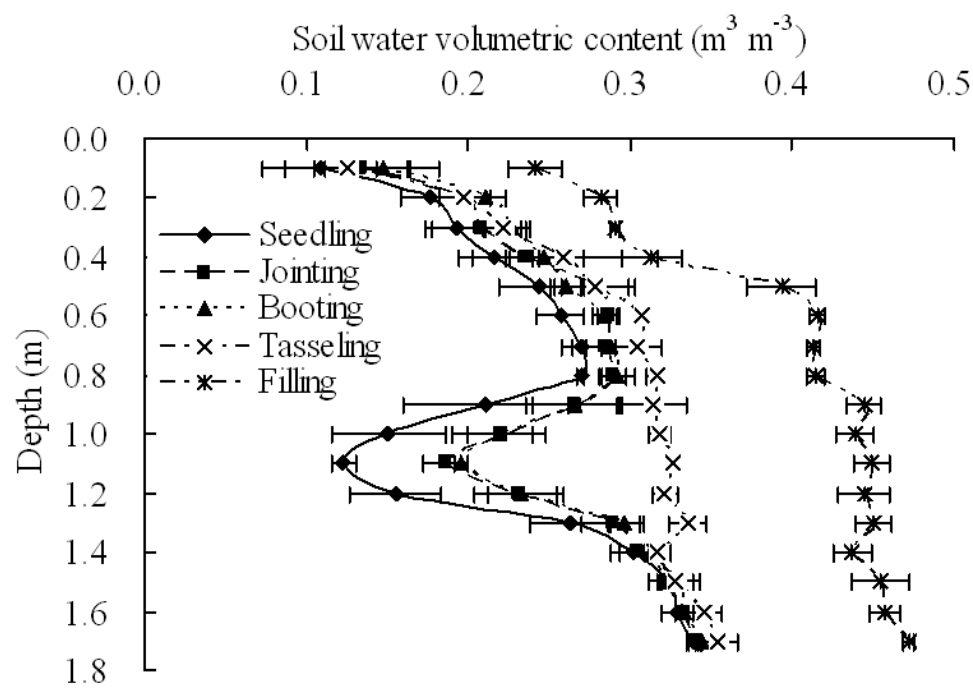

Figure 2. Average soil volumetric water content at different depths during each growth stage 


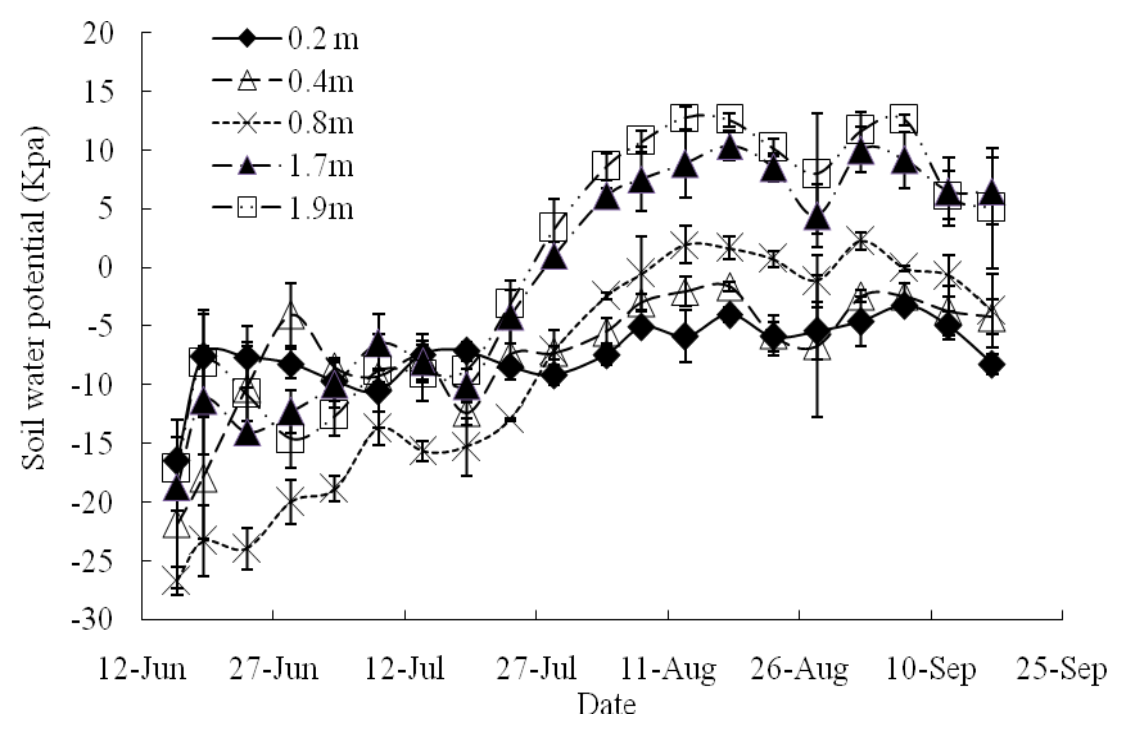

Figure 3. Average soil water potential at 20, 40 and $80 \mathrm{cmdepths} \mathrm{during} \mathrm{the} \mathrm{maize} \mathrm{growth} \mathrm{period}$ 